\title{
Penggunaan media sosial tidak berhubungan dengan pengetahuan mengenai COVID-19 pada masyarakat dewasa muda
}

\author{
Nur Najmi Raina, ${ }^{1}$ Kartini $^{2}$
}

\begin{abstract}
ABSTRAK
\section{LATAR BELAKANG}

Pandemi COVID-19 merupakan masalah kesehatan dunia. Di masa pandemi dengan kasus yang semakin bertambah membuat media sosial menjadi salah satu sumber informasi mengenai COVID-19. Penggunaan media sosial yang bijak sangat efektif untuk menyebarkan informasi dan pengetahuan mengenai pandemi COVID-19, sehingga membantu masyarakat untuk melakukan pencegahan COVID-19. Penelitian ini bertujuan menilai hubungan penggunaan media sosial dan pengetahuan COVID-19 pada dewasa muda.
\end{abstract}

\section{METODE}

Metode penelitian ini adalah analitik observasional dengan pendekatan cross-sectional, sampel penelitian sebanyak 240 responden, memenuhi kriteria inklusi dan eksklusi. Pengumpulan data dilakukan dengan wawancara menggunakan kuesioner online pada bulan Mei-Juli 2021 di Kelurahan Rorotan Jakarta Utara. Analisis data dilakukan dengan uji Chi-square dan Fisher's exact dengan tingkat kemaknaan $\mathrm{p}<0.05$.

\section{HASIL}

Reratausiaresponden $26.8 \pm 6.4$ tahun didominasioleh perempuan(65.4\%). Responden berpendidikan tinggi sebanyak $95.8 \%$, berpengetahuan baik mengenai COVID-19 sebanyak 54.2\%, tingkat penggunaan media sosial tinggi sebanyak $57.9 \%$. Responden dengan tingkat penggunaan media sosial tinggi dan berpengetahuan baik mengenai COVID-19 sebanyak $56.8 \%$. Tidak terdapat hubungan antara penggunaan media sosial, umur, dan pendidikan dengan pengetahuan COVID-19. Terdapat hubungan antara jenis kelamin dengan pengetahuan COVID-19.

\section{KESIMPULAN}

Penggunaan media sosial tidak berhubungan dengan tingkat pengetahuan COVID-19 pada masyarakat dewasa muda. Dibutuhkan media komunikasi lainnya untuk mengedukasi masyarakat dalam upaya pencegahan COVID-19.

Kata kunci: COVID-19, dewasa muda, media sosial, pengetahuan

\author{
${ }^{1}$ Program Studi Kedokteran, \\ Fakultas Kedokteran Universitas \\ Trisakti, Jakarta, Indonesia \\ ${ }^{2}$ Departemen Histologi, Fakultas \\ Kedokteran Universitas Trisakti, \\ Jakarta, Indonesia
Korespondensi:
Kartini
Departemen Histologi, Fakultas Kedokteran Universitas Trisakti, Jakarta, Indonesia Jalan Kyai Tapa (Kampus B) Usakti, Grogol, Indonesia 11440 Email: \\ kartiniedwin@trisakti.ac.id
}

J Biomedika Kesehat 2021;4(3):90-98 DOI: 10.18051/JBiomedKes.2021. v4.90-98

pISSN: 2621-539X / eISSN: 2621-5470

Artikel akses terbuka (open access) ini didistribusikan di bawah lisensi Creative Commons Attribution 4.0 International (CC-BY 4.0) 


\section{ABSTRACT}

\section{The use of social media has no association with knowledge about COVID-19 in young adults}

\section{BACKGROUND}

COVID-19 currently a world health problem. During the pandemic with increasing cases, social media has become one of the sources of information about COVID-19. Wise use of social media is very effective to disseminate knowledge about COVID-19 pandemic so as to help people to prevent COVID-19. This study aims to analyze the relationship between social media use and knowledge of COVID-19.

\section{METHODS}

A cross-sectional observational analysis study was conducted and a total of 240 respondents had fulfilled the inclusion and exclusion criteria. Data collection was carried out using online questionnaire interviews in May-July 2021 at Rorotan North Jakarta. Statistical analysis using Chi-Square and Fisher's exact test, level of significance were set at $\mathrm{p}<0.05$.

\section{RESULTS}

The mean age of respondents was $26.8 \pm 6.4$ years dominated by women $(65.4 \%)$. Respondents with highly educated (95.8\%), 54.2\% had good knowledge of COVID-19 and 57.9\% with a high social media usage. Respondents with high social media usage and had good knowledge COVID-19 (56.8\%). No significant association between social media use, age, and education with COVID-19 knowledge, but gender had significant association with COVID-19 knowledge.

\section{CONCLUSION}

The use of social media was not associated with the knowledge of COVID-19 in young adults. Other communication media are needed to educate the public in effort to prevent COVID-19.

Keywords: COVID-19, knowledge, social media, young adulthood

\section{PENDAHULUAN}

Seorang dewasa muda yang berusia antara 20-40 tahun berada dalam tahap kebutuhan yang besar untuk mengembangkan diri melalui hubungan interpersonal yang luas untuk saling berbagi pengalaman, bekerja sama, maupun bertukar informasi.(1) Kebutuhan akan informasi dapat dipenuhi melalui penggunaan media sosial yang sangat mudah diakses di era perkembangan teknologi informasi yang masif. ${ }^{(1)}$ Saat ini, informasi di media sosial mengguncangkan masyarakat tentang adanya pandemi COVID-19 yang berasal dari daerah Wuhan Provinsi Hubei, China. ${ }^{(2)}$ Pandemi ini disebabkan oleh Severe Acute Respiratory Syndrome-Corona Virus-2 (SARS$\mathrm{CoV}-2)$ suatu virus untaian tunggal RNA yang termasuk dalam keluarga Coronaviridae, ordo nidovirales, genus Betacorona-virus, ${ }^{(2,3)}$ dan sejak Maret 2020 virus ini melanda Indonesia. Penyakit ini bermanifestasi klinis dengan spektrum yang luas mulai dari gejala ringan bahkan sampai mengalami hipoksia dengan sindrom gagal nafas akut. ${ }^{(4,5)}$

Salah satu strategi pencegahan infeksi COVID-19 adalah dengan menjalankan protokol kesehatan secara benar dan untuk memahami hal itu masyarakat perlu mendapatkan pengetahuan tentang COVID-19, sehingga kualitas kesehatannya terjamin. ${ }^{(6)}$ Kondisi sosio demografi seperti usia, jenis kelamin, pekerjaan, pendidikan, status sosio ekonomi, termasuk akses informasi melalui media dapat memengaruhi tingkat pengetahuan seseorang. ${ }^{(6)}$ Selama masa pandemi dengan jumlah kasus yang semakin bertambah menyebabkan masyarakat menggunakan akses media sosial untuk mencari informasi tentang COVID-19.(7) Melalui media sosial informasi COVID-19 dapat menyebar dengan cepat, hanya membutuhkan hitungan menit informasi segera tersampaikan, sehingga menambah pengetahuan masyarakat untuk menyesuaikan keadaan dan melakukan pencegahan. ${ }^{(8)}$ Penyampaian informasi dengan menggunakan media yang ada menjadi salah satu cara menyediakan informasi yang tepat, menyebarkan pengetahuan tentang kesehatan, mencegah kepanikan massal karena informasi hoax, termasuk mengapresiasi kerja sama masyarakat dalam pencegahan infeksi. ${ }^{(9)}$

Penelitian di China mendapatkan hasil bahwa responden dengan usia rata-rata 24.1 tahun menunjukkan pengetahuan yang cukup baik mengenai COVID-19 dan sebagian besar responden mendapatkan informasi COVID-19 dari media sosial. ${ }^{(10)}$ Sedangkan penelitian di Kuwait 
mendapatkan hasil lebih dari $80 \%$ responden mengenali gejala COVID-19 dan mengetahui cara melindungi diri dari paparan virus ini. Cara mengakses informasi mengenai COVID-19 terutama didapatkan dari media sosial $(83.5 \%)$ diikuti oleh informasi dari WHO (50.1\%). ${ }^{(11)}$

Penelitian Sari et al. menemukan adanya hubungan antara umur, pendidikan, dan akses media sosial dengan pengetahuan pencegahan COVID-19. ${ }^{(6)}$ Sedangkan penelitian di Yordania menemukan hubungan yang signifikan antara penggunaan platform media sosial dengan pengetahuan dan kesadaran masyarakat akan kesehatan, perubahan perilaku masyarakat, dan pencegahan COVID-19. ${ }^{(12)}$ Selain itu, penelitian Li et al. menyatakan bahwa frekuensi penggunaan media sosial secara signifikan memengaruhi perilaku pencegahan COVID-19. ${ }^{(9)}$

Terdapat penelitian dengan subjek dewasa muda berusia 18-25 tahun di Karachi, Pakistan, menemukan adanya kekurangan pengetahuan maupun kesadaran dalam mengenali gejala coronavirus. Sebanyak 56.6\% responden menyatakan bahwa coronavirus merupakan virus paling berbahaya di dunia dan sebanyak $43 \%$ tidak setuju bahwa virus flu biasa berpotensi lebih berbahaya dibandingkan coronavirus. Namun, sebagian besar responden mengetahui cara transmisi virus ini, langkah pencegahan dan antisipasi bila berhadapan dengan pasien COVID-19. Platform terbanyak yang digunakan untuk mendapatkan informasi mengenai COVID-19 adalah media sosial, diikuti televisi, dan media cetak. ${ }^{(13)}$ Penelitian lainnya mengatakan bahwa kelompok usia memengaruhi pengetahuan yang didapat, di mana kelompok usia rentan dengan pendidikan rendah lebih cenderung mendapatkan informasi yang salah melalui media sosial, sedangkan kelompok usia muda berpendidikan tinggi mendapatkan pengetahuan yang baik melalui media sosial..$^{(14)}$

Suatu tinjauan oleh Gabarron et al. menyatakan bahwa proporsi misinformasi tentang COVID-19 yang didapatkan dari postingan di media sosial berkisar antara $0.2 \%$ dan $28.8 \%$ dan hal ini berefek pada rasa takut, panik, dan stres yang berhubungan dengan COVID-19. ${ }^{(15)}$ Penelitian Ahmad et al. di Irak menyimpulkan bahwa dewasa muda di Irak yang berusia 18-35 tahun menghadapi gangguan kecemasan akibat pandemi dan responden melaporkan bahwa penggunaan media sosial berdampak pada kesehatan mentalnya. Melalui penelitian ini didapatkan korelasi positif antara penggunaan media sosial dengan penyebaran kepanikan yang berhubungan dengan pandemi. Facebook merupakan platform media sosial terbanyak dalam menyebar ketakutan $(82.6 \%) .{ }^{(7)}$ Penelitian Kim et al. yang bertujuan menilai persepsi tentang informasi kesehatan di situs jejaring sosial, khususnya mengenai kredibilitas dan kegunaan informasi kesehatan di Facebook, menyimpulkan bahwa responden cenderung menganggap informasi kesehatan dengan sumber informasi berasal dari organisasi kesehatan lebih dapat dipercaya, dibandingkan dengan sumber informasi non profesional pada Facebook. ${ }^{(16)}$

Berdasarkan penelitian sebelumnya diketahui bahwa akses informasi melalui media sosial dapat memengaruhi pengetahuan seseorang. Namun, hasilnya pun masih ada yang kontra, dan penggunaan media sosial yang salah justru berdampak negatif bagi kesehatan mental. Penelitian ini bertujuan menilai hubungan penggunaan media sosial dengan pengetahuan mengenai COVID-19 pada masyarakat dewasa muda.

\section{METODE}

Desain penelitian adalah observasional analitik dengan pendekatan studi potong lintang (cross-sectional) yang dilaksanakan pada AprilMei 2021. Penelitian berlokasi di Kelurahan Rorotan Kecamatan Cilincing Jakarta Utara yang terdiri dari $11 \mathrm{RW}$ dan 116 RT. Populasi penelitian adalah masyarakat dewasa muda. Metode pengambilan sampel adalah sebagai berikut: dari 11 RW dipilih 6 RW secara cluster random sampling, yaitu RW 01, 02, 03, 06, 08, 10; dan dari masing-masing RW terpilih dilakukan simple random sampling untuk memilih RT. Selanjutnya kuesioner disebarkan ke RW melalui grup WhatsApp dan diteruskan ke forum warga di masing-masing RT terpilih. Selain itu, kuesioner juga disebarkan melalui forum JUMANTIK dan ROBUSTA. Responden berusia dewasa muda yang mengisi kuesioner dipilih dengan memerhatikan kriteria inklusi, yaitu masyarakat berusia 20-40 tahun, berjenis kelamin laki-laki dan perempuan, pengguna media sosial (Twitter, 
Facebook, Instagram, WhatsApp, YouTube, Line, TikTok), mampu mengisi kuesioner online serta bersedia berpartisipasi dengan menyetujui pengisian kuesioner secara lengkap. Responden yang mendapatkan informasi COVID-19 dari sumber lainnya misalnya dari tenaga kesehatan atau media lainnya selain media sosial, akan dieksklusi. Jumlah sampel yang didapat sebanyak 240 responden.

Untuk mendapatkan data mengenai pengetahuan masyarakat mengenai COVID-19 digunakan kuesioner yang menilai dua komponen pengetahuan, yaitu pengetahuan masyarakat dan pengetahuan pribadi, meliputi gambaran umum COVID-19, gejala, transmisi, faktor risiko, terapi, pencegahan, bahaya COVID-19, etika batuk dan bersin, penggunaan masker dan cara mencuci tangan. Setiap pertanyaan memiliki beberapa pilihan jawaban, termasuk pertanyaan yang benar dan salah. Nilai dari setiap jawaban benar yang dipilih adalah 1 , jika tidak dipilih nilainya 0 . Nilai dari setiap pilihan jawaban salah yang dipilih adalah 0 , sedangkan jika tidak dipilih nilainya 1 . Untuk mengukur persentase dari jawaban yang didapat yaitu jumlah nilai individu (0-53) dibagi total opsi jawaban (53) dikalikan 100. Selanjutnya persentase nilai individu dikategorikan menjadi dua tingkatan yaitu baik dan tidak baik. ${ }^{(17)}$ Untuk memudahkan pengkategoriannya dilakukan uji normalitas dengan uji Kolmogorov-smirnov dan diperoleh data terdistribusi tidak merata oleh karenanya digunakan nilai median sebagai titik potong dalam menentukan kategori baik (skor 274) dan tidak baik (skor <74). ${ }^{(18)}$ Kuesioner penggunaan media sosial menggunakan skala Likert terdiri dari 5 poin, mulai dari sangat tidak setuju hingga sangat setuju. Presentasi nilai dikategorikan menjadi 2 tingkatan yaitu tinggi (skor $\geq 72$ ) dan rendah (skor $<72$ ). Analisis statistik menggunakan uji Chi-square dan Fisher's Exact dengan tingkat kemaknaan $\mathrm{p}<0.05$. Penelitian ini telah mendapat persetujuan etik riset dari Komisi Etik Riset Fakultas Kedokteran Universitas Trisakti dengan Nomor: 31//KER-FK/2/2021.

\section{HASIL}

Gambaran distribusi karakteristik responden dapat dilihat pada Tabel 1. Berdasarkan data jumlah responden sebanyak 240 orang, rerata usianya adalah 26.8 tahun yang didominasi oleh jenis kelamin perempuan sebanyak 157 orang (65.4\%). Berdasarkan tingkat pendidikannya, sebagian besar responden berpendidikan tinggi yaitu berjumlah 230 orang (95.8\%).

\section{Tabel 1. Distribusi karakteristik responden}

\begin{tabular}{lcc}
\hline Variabel & $\mathbf{n}$ & $\mathbf{\%}$ \\
\hline Umur & & \\
Rerata \pm SD & $26.8 \pm 6.4$ & \\
Jenis kelamin & & \\
Laki-laki & 83 & 34.6 \\
$\begin{array}{l}\text { Perempuan } \\
\text { Tingkat pendidikan }\end{array}$ & 157 & 65.4 \\
Rendah: tidak sekolah/ & & \\
SD/ SMP/sederajat & 10 & 4.2 \\
Tinggi (perguruan tinggi/ & & \\
D3/SMA/SMK/sederajat) & 230 & 95.8 \\
Pengetahuan COVID-19 & & \\
Baik & 130 & 54.2 \\
Kurang baik & 110 & 45.8 \\
Penggunaan media sosial & & \\
Tinggi & 139 & 57.9 \\
Rendah & 101 & 42.1 \\
\hline
\end{tabular}

Berdasarkan analisis univariat, sebagian besar responden memiliki tingkat pengetahuan mengenai COVID-19 dengan kategori baik, yaitu sebanyak 130 orang (54.2\%). Sebanyak 139 orang $(57.9 \%)$ merupakan pengguna media sosial kategori tinggi dengan platform media sosial yang paling banyak digunakan oleh responden, yaitu WhatsApp dengan persentase 90\% (Gambar 1).

Berdasarkan Tabel 2, hasil penelitian menunjukkan bahwa responden yang memiliki tingkat penggunaan media sosial tinggi dengan pengetahuan baik mengenai COVID-19 sebanyak 79 orang $(56.8 \%)$. Sedangkan responden yang memiliki tingkat penggunaan media sosial rendah dengan pengetahuan kurang baik sebanyak 50 orang (49.5\%). Analisis statistik menggunakan uji Chi-square didapatkan nilai $\mathrm{p}=0.400$, sehingga disimpulkan tidak terdapat hubungan yang bermakna antara penggunaan media sosial dengan pengetahuan COVID-19.

Kelompok umur dengan rentang 2030 tahun memiliki pengetahuan baik mengenai COVID-19 sebanyak 95 orang (56.2\%) dan responden dengan rentang umur 31-40 tahun berpengetahuan kurang baik sebanyak 36 orang (50.7\%). Analisis statistik menggunakan uji Chi-square didapatkan nilai $\mathrm{p}=0.401$, sehingga 


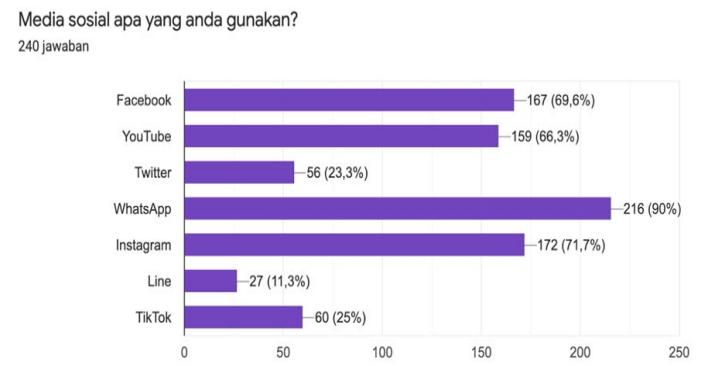

Gambar 1. Jenis media sosial yang digunakan

disimpulkan tidak terdapat hubungan yang bermakna antara umur dengan pengetahuan COVID-19. Berdasarkan jenis kelamin didominasi oleh perempuan, yaitu menunjukkan bahwa 102 orang $(65.0 \%)$ perempuan memiliki pengetahuan baik, sedangkan responden laki-laki memiliki tingkat pengetahuan kurang baik sebanyak 55 orang (66.3\%). Analisis statistik menggunakan uji Chi-square didapatkan nilai $\mathrm{p}=0.000$, disimpulkan bahwa terdapat hubungan yang bermakna antara jenis kelamin dengan pengetahuan COVID-19.

Hasil penelitian berdasarkan tingkat pendidikan diperoleh hasil sebanyak 126 (54.8\%) responden berpendidikan tinggi dan memiliki pengetahuan baik mengenai COVID-19. Sedangkan sebanyak 6 orang $(60.0 \%)$ responden dengan pendidikan rendah memiliki pengetahuan kurang baik mengenai COVID-19. Analisis statistik menggunakan uji Fisher's Exact disimpulkan bahwa tidak terdapat hubungan yang bermakna antara tingkat pendidikan dengan pengetahuan COVID-19 dengan nilai $p=0.519$.

\section{PEMBAHASAN}

Rerata usia pengguna media sosial dalam penelitian ini adalah 26.8 tahun. Berdasarkan data Asosiasi Penyelenggara Jasa Internet Indonesia pada tahun 2017 tercatat sekitar 49.52\% pengguna internet berusia 19-34 tahun. ${ }^{(17)}$ Selain itu, dominasi responden di penelitian ini adalah perempuan $(65.4 \%)$, sejalan dengan penelitian Moudy et al. yang mendapatkan hasil sebanyak $76.2 \%$ subjek penelitiannya adalah perempuan. (17) Karakteristik penggunaan media sosial untuk mendapatkan informasi antara seorang lakilaki dengan perempuan cenderung berbeda. Laki-laki biasanya mengakses media untuk membaca berita ekonomi, informasi olahraga atau cuaca, sedangkan seorang perempuan lebih menyukai informasi terkait kesehatan atau agama. ${ }^{(7,18)}$ Dominasi jenis kelamin perempuan pada penelitian ini dikarenakan topik penelitian berhubungan dengan kesehatan, yaitu COVID-19 dan perempuan lebih tertarik dengan topik ini. Penelitian Sari et al. juga mendapatkan hasil yang sama, yaitu sebanyak $79.8 \%$ subjek penelitiannya adalah perempuan. Bila dibandingkan dengan laki-laki, perempuan memiliki waktu lebih banyak untuk membaca dan berdiskusi tentang bagaimana

Tabel 2. Hubungan karakteristik responden, penggunaan media sosial dengan pengetahuan COVID-19

\begin{tabular}{|c|c|c|c|c|c|}
\hline \multirow{3}{*}{ Variabel } & \multicolumn{4}{|c|}{ Pengetahuan mengenai COVID-19 } & \multirow{3}{*}{ Nilai $_{f}$} \\
\hline & \multicolumn{2}{|c|}{ Baik } & \multicolumn{2}{|c|}{ Kurang Baik } & \\
\hline & $\mathbf{n}$ & $\%$ & $\mathbf{n}$ & $\%$ & \\
\hline \multicolumn{6}{|l|}{ Umur } \\
\hline 20-30 tahun & 95 & 56.2 & 74 & 43.8 & \multirow{2}{*}{$0.401^{*}$} \\
\hline $31-40$ tahun & 35 & 49.3 & 36 & 50.7 & \\
\hline \multicolumn{6}{|c|}{ Jenis kelamin } \\
\hline Laki-laki & 28 & 33.7 & 55 & 66.3 & \multirow{2}{*}{$0.000^{*}$} \\
\hline Perempuan & 102 & 65.0 & 55 & 35.0 & \\
\hline \multicolumn{6}{|c|}{ Tingkat pendidikan } \\
\hline Rendah & 4 & 40.0 & 6 & 60.0 & \multirow{2}{*}{$0.519^{\#}$} \\
\hline Tinggi & 126 & 54.8 & 104 & 45.2 & \\
\hline \multicolumn{6}{|c|}{ Penggunaan media sosial } \\
\hline Tinggi & 79 & 56.8 & 60 & 43.2 & \multirow{2}{*}{$0.400^{*}$} \\
\hline Rendah & 51 & 50.5 & 50 & 49.5 & \\
\hline
\end{tabular}

${ }^{*}$ Uji Chi-square $(\mathrm{p}<0.05$ berbeda bermakna)

\# Uji Fisher's Exact 
pencegahan COVID-19, sehingga memiliki pengetahuan yang lebih baik tentang pencegahan infeksi virus ini. ${ }^{(6)}$ Responden dalam penelitian ini memiliki tingkat pendidikan tinggi (perguruan tinggi/D3/SMA/SMK/sederajat sebanyak 95.8\%). Hal ini sejalan dengan penelitian Moudy et al. dengan hasil sebanyak $46.4 \%$ memiliki pendidikan terakhir SMA/sederajat dan 52.6\% adalah lulusan perguruan tinggi/akademi. ${ }^{(17)}$

Temuan dalam penelitian ini mengenai pengetahuan COVID-19 menunjukkan sebagian besar subjek dewasa muda memiliki pengetahuan baik mengenai COVID-19 (54.2\%). Hal ini dikarenakan responden memiliki tingkat pendidikan tinggi, yang memengaruhi seseorang bersikap bijak dalam menggunakan media sosial untuk mendapatkan informasi yang spesifik, valid, dan dapat dipertanggungjawabkan, sehingga meningkatkan pengetahuan terkait COVID-19 dan pencegahannya. Sejalan dengan penelitian sebelumnya yang menunjukkan bahwa masyarakat Ngronggah memiliki pengetahuan yang baik tentang penyakit COVID-19 dengan persentase $69.35 \%$. Dikatakan bahwa pengetahuan yang baik akan memengaruhi perilaku seseorang. ${ }^{(19)}$

Dari penelitian ini juga didapatkan hasil bahwa penggunaan media sosial termasuk kategori tinggi (57.9\%). Penelitian Moudy et al. menyatakan bahwa mayoritas responden yaitu sebesar $79.1 \%$ menggunakan media sosial untuk mendapatkan informasi mengenai COVID-19. Oleh karenanya, penggunaan media sosial dapat menjadi media edukasi untuk meningkatkan pengetahuan COVID-19 terutama pada masyarakat. ${ }^{(17)}$ WhatsApp merupakan platform media sosial yang paling banyak digunakan untuk kebutuhan masyarakat dewasa muda pada penelitian ini, hal ini sejalan dengan penelitian Asiati et al. mengenai karakteristik pengguna media sosial yang menyatakan bahwa platform jejaring sosial yang paling banyak digunakan, yaitu WhatsApp sebesar 71\%. ${ }^{(20)}$ Penelitian Abdelhafiz et al. pada masyarakat Mesir menemukan bahwa informasi tentang COVID-19 terbanyak didapatkan dari media sosial (66.9\%) namun, platform utamanya adalah Facebook. ${ }^{(21)}$ Hasil yang berbeda didapatkan penelitian Yuniarto et al. bahwa media penyampaian informasi mengenai COVID-19 yang efektif adalah melalui smartphone karena media ini banyak digunakan kaum milenial yang merupakan responden utama penelitian tersebut. (22)

Berdasarkan penelitian ini tidak didapatkan hubungan yang bermakna antara penggunaan media sosial dan pengetahuan COVID-19. Hasil tersebut dapat disebabkan banyaknya informasi yang tidak benar (hoax) yang beredar melalui media sosial menyebabkan masyarakat kurang percaya dengan informasi yang didapat. Gabarron et al. menyatakan bahwa proporsi misinformasi tentang COVID-19 yang didapatkan dari postingan di media sosial berkisar antara $0.2 \%$ dan $28.8 \%$ dan hal ini berefek pada rasa takut, panik, dan stres yang berhubungan dengan COVID-19. ${ }^{(15)}$ Penelitian oleh Yuniarto et al. menyatakan bahwa penggunaan media sosial tidak efektif dalam penyampaian informasi di masyarakat, sebab terkadang informasi tentang COVID-19 yang diterima tidak dipahami secara utuh dan hal ini berdampak secara tidak langsung dalam proses meneruskan pesan tersebut melalui media sosial. Efek lebih lanjutnya tidak terjadinya suatu perubahan baik pengetahuan maupun perilaku masyarakat dalam upaya mengakhiri pandemi. (22) Pengetahuan yang diperoleh masyarakat selain dari media sosial dapat berasal dari sumber lainnya, misalnya smartphone, website, televisi atau media lainnya. Hal ini dapat memengaruhi hasil yang tidak bermakna dalam penelitian ini, walaupun hal tersebut berusaha diminimalisir dengan mengeksklusi informasi yang bukan dari media sosial, namun mengingat masifnya informasi tentang COVID-19 yang dibagikan lewat berbagai media tidak menutup kemungkinan responden juga mendapatkan informasi tersebut.

Temuan ini tidak sejalan dengan penelitian Sari et al. yang menyimpulkan adanya hubungan akses media sosial dengan pengetahuan pencegahan COVID-19 pada masyarakat pesisir Kecamatan Wawolesa. Temuan penelitian tersebut menyatakan bahwa masyarakat di sana mudah mengakses media sosial untuk memperoleh banyak informasi terkait pencegahan COVID-19 yang disebarkan oleh lembaga resmi maupun sesama masyarakat. ${ }^{(6)}$ Hal yang sama juga dikemukakan oleh penelitian Al-Dmour et al. di Yordania yang menyatakan bahwa secara signifikan terdapat hubungan antara penggunaan platform media sosial dengan pengetahuan dan 
kesadaran masyarakat akan kesehatan serta perubahan perilaku masyarakat dalam upaya pencegahan COVID-19. Hal ini dikarenakan banyaknya kampanye kesehatan yang dilakukan melalui media sosial untuk memberikan informasi kepada masyarakat, sehingga memengaruhi pengetahuan dan perilaku pencegahan COVID-19. Penelitian Al-Dmour ini mendukung penggunaan platform media sosial terutama untuk kesehatan masyarakat dan kampanye media sosial dianggap sebagai komponen penting pendekatan komprehensif untuk meningkatkan perilaku kesehatan masyarakat. ${ }^{(12)}$

Dari penelitian ini terdapat perbedaan sebesar $7.3 \%$ antara pengguna media sosial yang memiliki pengetahuan baik tentang COVID-19 dengan pengguna media sosial yang pengetahuannya kurang. Responden dengan tingkat penggunaan media sosialnya tinggi dan memiliki pengetahuan baik mengenai COVID-19, sebagian besar responden dapat menjawab pertanyaan mengenai COVID-19 dengan benar. Hal ini karena pertanyaan yang diberikan mudah dipahami dan bersifat mendasar dan sering dipromosikan organisasi kesehatan melalui platform media sosial. Dengan mengakses informasi melalui media sosial hal tersebut dapat meningkatkan pengetahuan dan merupakan salah satu usaha pencegahan COVID-19. ${ }^{(17)}$ Akan tetapi responden yang pengetahuannya kurang baik mengenai COVID-19 dengan tingkat penggunaan media sosial rendah kemungkinan kurang mendapatkan informasi terpercaya yang didapatkan dari berbagai media dan organisasi kesehatan. Hal ini dapat dilihat dari jawaban responden mengenai informasi yang salah, namun masih dipercaya.

Penelitian ini menyimpulkan bahwa tidak terdapat hubungan yang bermakna antara umur dengan pengetahuan mengenai COVID-19 pada masyarakat dewasa muda dikarenakan kebutuhan informasi COVID-19 dan keterpaparan informasi adalah sama untuk semua kelompok usia selama masa pandemi COVID-19. Sejalan dengan penelitian oleh Wulandari A et al. di Kalimantan Selatan, menunjukkan bahwa responden usia dewasa memiliki pengetahuan baik dengan persentase $77.1 \%$ dan tidak terdapat hubungan bermakna antara umur dengan pengetahuan masyarakat terkait pencegahan COVID-19, karena keterpaparan informasi adalah sama untuk semua masyarakat dengan berbagai kategori umur. ${ }^{(23)}$ Berbeda dengan penelitian oleh Sari et al. yang menyimpulkan terdapat hubungan bermakna antara umur dan pengetahuan mengenai pencegahan COVID-19. Hal ini dikarenakan pada usia muda yang termasuk golongan milenial memiliki risiko tinggi terpapar informasi COVID-19 terlebih didukung dengan adanya kebijakan pemerintah di masa pandemi untuk melakukan kegiatan di rumah saja menyebabkan usia muda lebih banyak waktu dan mudah mendapat akses informasi mengenai COVID-19. ${ }^{(6)}$

Pengetahuan seseorang juga dipengaruhi oleh jenis kelaminnya dan menurut hasil penelitian ini pada masyarakat dewasa muda didapatkan hubungan yang bermakna antara jenis kelamin dengan pengetahuan mengenai COVID-19. Hal ini sejalan dengan penelitian sebelumnya yang menyatakan pengetahuan responden perempuan lebih baik dibandingkan responden laki-laki dan didapatkan hubungan antara gender dengan pengetahuan tentang pencegahan COVID-19. Seorang perempuan memiliki lebih banyak waktu untuk berdiskusi dan mencari informasi mengenai bagaimana cara mencegah terpapar COVID-19. ${ }^{(23)}$

Penelitian oleh Abdelhafiz et al. menyimpulkan bahwa tidak terdapat hubungan yang signifikan antara jenis kelamin dengan pengetahuan tentang COVID-19. Responden penelitian tersebut didominasi oleh perempuan dan informasi yang diperoleh lebih banyak melalui media sosial (66.9\%). ${ }^{(21)}$ Perbedaan hasil penelitian ini dikarenakan beberapa hal yaitu pada penelitian Abdelhafiz et al. jenis kelamin perempuan lebih mendominasi dibandingkan laki-laki, namun pada hasil data pengetahuan mengenai COVID-19 pada perempuan dan lakilaki didapatkan tidak terdapat perbedaan yang signifikan dengan skor pengetahuan hampir sama, yaitu pada perempuan nilai mean dan SD (16.27 \pm 2.63$)$ dan pada laki-laki (16.46 \pm 2.62), sehingga persamaan hasil pengetahuan menyebabkan tidak terdapatnya hubungan antara jenis kelamin dengan pengetahuan COVID-19. (21) Menurut penelitian ini perempuan cenderung memiliki tingkat pengetahuan baik mengenai COVID-19, hal ini dikarenakan perempuan lebih banyak menggunakan waktunya untuk membaca di berbagai media dan topik kesehatan lebih 
diminati dibandingkan laki-laki. Individu berjenis kelamin laki-laki berisiko 1.37 kali memiliki tindakan yang tidak baik dalam upaya pencegahan COVID-19 dibandingkan individu berjenis kelamin perempuan. ${ }^{(24)}$

Berdasarkan tingkat pendidikan menunjukan bahwa tidak terdapat hubungan yang bermakna antara tingkat pendidikan dengan pengetahuan COVID-19. Sama halnya dengan penelitian oleh Pratiwi et al. yang menyatakan bahwa tidak terdapat hubungan yang signifikan antara karakteristik pendidikan terakhir dengan tingkat pengetahuan mengenai COVID-19. (25) Berbeda halnya dengan penelitian yang dilakukan oleh Zhong et al. menyimpulkan bahwa terdapat hubungan signifikan tingkat pendidikan dengan pengetahuan mengenai COVID-19, hal ini dikarenakan tingkat pendidikan tinggi dengan pengetahuan baik mengenai COVID-19 memengaruhi tindakan responden, sebagian besar responden memiliki tindakan yang baik (tidak mengunjungi tempat ramai dan menggunakan masker saat keluar) dengan status sosial ekonomi relatif tinggi yang memudahkan untuk mendapatkan informasi mengenai COVID-19. (24) Seseorang yang berpendidikan tinggi cenderung lebih mudah mendapatkan akses informasi dari berbagai media yang tentunya memengaruhi pengetahuan yang didapat. Faktor lain yang juga berpengaruh terhadap pengetahuan yaitu pengalaman pribadi, pendidikan yang diperoleh baik formal maupun informal, pengalaman orang lain, lingkungan, serta media massa. ${ }^{(26)}$

Perkembangan era digital yang sangat pesat membuat akses informasi sangat mudah diperoleh. Implikasi dari penelitian ini adalah agar masyarakat memahami pentingnya menggunakan media sosial secara bijaksana dalam mengakses informasi khususnya mengenai COVID-19 selama masa pandemi ini. Sikap dan perilaku masyarakat dapat berubah lebih positif bila mendapatkan pengetahuan yang benar, sehingga upaya pemutusan rantai penularan COVID-19 dapat terwujud.

Keterbatasan penelitian ini hanya menilai hubungan penggunaan media sosial dan pengetahuan COVID-19 dan tidak menilai variabel lain seperti media massa, media elektronik atau pun media daring lainnya yang kemungkinan juga memengaruhi pengetahuan COVID-19.
Selain itu, desain yang digunakan adalah desain potong silang, sehingga tidak dapat menunjukkan hubungan sebab akibat antar variabelnya.

\section{KESIMPULAN}

Sebagian besar responden berusia dewasa muda memiliki pengetahuan baik mengenai COVID-19 dan tingkat penggunaan media sosial untuk mendapatkan informasi COVID-19 didominasi kategori tinggi namun tidak terdapat hubungan yang bermakna antara penggunaan media sosial dengan pengetahuan COVID-19 pada masyarakat dewasa muda. Dibutuhkan media komunikasi lain yang mudah di akses untuk mengedukasi masyarakat dalam upaya pencegahan COVID-19.

Disarankan kepada institusi kesehatan setempat untuk meningkatkan upaya promosi kesehatan mengenai COVID-19 melalui berbagai media yang dapat di akses masyarakat dengan mudah. Diharapkan dapat dilakukan penelitian lebih lanjut untuk menilai media mana yang sesungguhnya dapat digunakan secara efektif untuk mengedukasi masyarakat sehingga menghasilkan perubahan perilaku ke arah yang lebih baik terutama terkait penanggulangan pandemi COVID-19.

\section{KONFLIK KEPENTINGAN}

Penulis tidak mempunyai konflik kepentingan saat melakukan penyusunan artikel ini.

\section{REFERENSI}

1. Maheswari J, Dwiutami L. Pola perilaku dewasa muda yang kecenderungan kecanduan situs jejaring sosial. JPPP. 2013;2(1):51-62. doi:10.21009/JPPP

2. Isbaniah F, Susanto AD. Pneumonia corona virus infection disease-19 (COVID-19). J Indon Med Assoc. 2020;70(4):87-94. doi: 10.47830/jinmavol.70.4-2020-235

3. Parwanto M. Virus Corona (2019-nCoV) penyebab COVID-19. J Biomedika Kesehat. 2020;3(1):1-2. doi: 10.18051/JBiomedKes.2020.v3.1-2

4. Isbaniah F, Kusumowardhani D, Sitompul PA, et al. Pedoman Pencegahan dan Pengendalian Coronavirus Disease (COVID-19). 4th ed. Aziza L, Aqmarina A, Ihsan M, editors. Jakarta: Kementrian Kesehatan RI; 2020.

5. Kumar P, Kumar M, Bedi O, et al. Role of vitamins and minerals as immunity boosters in COVID-19. Inflammopharmacology. 2021;29:1001-16. doi: 10.1007/s10787-021-00826-7

6. Sari NI, Jumakil, Fithria. Hubungan sosio demografi dan akses media sosial dengan pengetahuan pencegahan COVID-19 pada masyarakat pesisir Kecamatan Wawolesea tahun 
2020. Endem J [Internet]. 2021;2(1):1-8. Available from: http://ojs.uho.ac.id/index.php/Endemis/ article/view/19594

7. Ahmad AR, Murad HR. The impact of social media on panic during the COVID-19 pandemic in Iraqi Kurdistan: Online questionnaire study. J Med Internet Res. 2020;22(5):e19556. doi: 10.2196/19556: 10.2196/19556

8. Sukesih S, Usman U, Budi S, et al. Pengetahuan dan sikap mahasiswa kesehatan tentang pencegahan COVID-19 di Indonesia. J Ilmu Keperawatan dan Kebidanan. 2020;11(2):258-64. doi: 10.26751/ jikk.v11i2.835

9. Li X, Liu Q. Social media use, eHealth literacy, disease knowledge, and preventive behaviors in the COVID-19 pandemic: cross-sectional study on Chinese netizens. J Med Internet Res. 2020;22(10):e19684. doi: 10.2196/19684 $10.2196 / 19684$

10. Xu H, Mendez MJG, Guo L, et al. Knowledge, awareness, and attitudes relating to the COVID-19 pandemic among different populations in Central China: Cross-Sectional Survey. J Med Internet Res. 2020; 22(10): e22628. doi: 10.2196/22628

11. Ali KF, Whitebridge S, Jamal $\mathrm{MH}$, et al. Perceptions, knowledge, and behaviors related to COVID-19 among social media users: Crosssectional study. J Med Internet Res. 2020; 22(9): e19913. doi: 10.2196/19913

12. Al-Dmour H, Masa'deh R, Salman A, et al. Influence of social media platforms on public health protection against the COVID-19 pandemic via the mediating effects of public health awareness and behavioral changes: Integrated model. J Med Internet Res. 2020; 22(8):3-5. doi: 10.2196/19996

13. Mubeen SM, Kamal S, Kamal S, et al. Knowledge and awareness regarding spread and prevention of COVID-19 among the young adults of Karachi. J Pak Med Assoc. 2020; 70(5):172-4. doi: 10.5455/ JPMA.40

14. Zhou J, Ghose B, Wang R, et al. The health perceptions and misconceptions regarding COVID-19: spreading mechanism and elimination strategy in China. J Med Internet Res. 2020; 22(11): e21099. doi: 10.2196/21099

15. Gabarron E, Oyeyemi SO, Wynn R. Covid19-related misinformation on social media: A systematic review. Bull World Health Organ. 2021; 99(6): 455-63. doi: 10.2471/BLT.20.276782

16. Kim SU, Syn SY. Credibility and usefulness of health information on Facebook: A survey study with U.S. college students. Information Research [Internet]. 2016; 21(4):727. Available from: http:// www.informationr.net/ir/21-4/paper727.html

17. Moudy J, Syakurah RA. Pengetahuan terkait usaha pencegahan Coronavirus Disease (COVID-19) di Indonesia. Higeia J Public Heal Res Dev. 2020; 4(3):335-42. doi: 10.15294/higeia/v4i3/37844

18. Rachmani AS, Budiyono, Dewanti NAY Pengetahuan, sikap dan praktik pencegahan COVID-19 pada masyarakat kota Depok, Jawa Barat. MPPKI. 2020;4(1):97-103. doi: 10.31934/ mppki.v2i3

19. Sari DP, Atiqoh NS. Hubungan antara pengetahuan masyarakat dengan kepatuhan penggunaan masker sebagai upaya pencegahan penyakit COVID-19 di Ngronggah. Infokes: J Ilmiah Rekam Medis dan Informasi Kesehatan. 2020;10(1):52-5. doi: 10.47701/infokes.v10i1.850

20. Asiati DI, Septadiyanto S. Karakteristik pengguna media sosial. MBIA. 2018;17(3):25-35. doi: $10.33557 / 10.33557 / \mathrm{mbia} . \mathrm{v} 17 \mathrm{i} 3.158$

21. Abdelhafiz AS, Mohammed Z, Ibrahim ME, et al. Knowledge, perceptions, and attitude of Egyptians towards the novel Coronavirus Disease (COVID-19). JCH 2020;45:881-90. doi: 10.1007/s10900-020-00827-7

22. Yuniarto D, Khozinaturrohmah HN, Abd. Rahman AB. Effectiveness of Covid-19 Information through social media based on public intention. Appl Inf Syst Manag. 2021;4(1):37-44. doi: 10.15408/aism.v4i1.19457

23. Wulandari A, Rahman F, Pujianti N, et al. Hubungan karakteristik individu dengan pengetahuan tentang pencegahan Coronavirus Disease 2019 pada masyarakat di Kalimantan Selatan. JKMI. 2020;15(1):43-5. doi: 10.26714/ jkmi.15.1.2020.42-46

24. Zhong BL, Luo W, Li HM, et al. Knowledge, attitudes, and practices towards COVID-19 among Chinese residents during the rapid rise period of the COVID-19 outbreak: a quick online crosssectional survey. Int J. Biol. Sci 2020;16(10):174652. doi: $10.7150 /$ ijbs.45221

25. Pratiwi MSA, Yani MVW, Putra AIYD, et al. Hubungan karakteristik individu terhadap perilaku mengenai Covid-19 di Desa Gulingan, Mengwi, Bali. J Kes. 2020;13(2):112. doi: 10.24252/ kesehatan.v1i1.16340

26. Siltrakool B. Assessment of community pharmacists, knowledge, attitude and practice regarding non-prescription antimicrobial use and resistance in Thailand [tesis]. [Hatfield]: University of Hertfordshire; 2017. $130 \mathrm{p}$. 